Maurer School of Law: Indiana University

Digital Repository @ Maurer Law

1988

\title{
Legal History and Social Science: Friedman's History of American Law, the Second Time Around
}

Michael Grossberg

Indiana University-Bloomington, grossber@indiana.edu

Follow this and additional works at: https://www.repository.law.indiana.edu/facpub

Part of the Legal History Commons, and the United States History Commons

\section{Recommended Citation}

Grossberg, Michael, "Legal History and Social Science: Friedman's History of American Law, the Second Time Around" (1988). Articles by Maurer Faculty. 2152.

https://www.repository.law.indiana.edu/facpub/2152

This Book Review is brought to you for free and open access by the Faculty Scholarship at Digital Repository @ Maurer Law. It has been accepted for inclusion in Articles by Maurer Faculty by an authorized administrator of Digital Repository @ Maurer Law. For more information, please contact rvaughan@indiana.edu. 


\section{Legal History and Social Science: Friedman's History of American Law, the Second Time Around}

\section{Michael Grossberg}

Lawrence M. Friedman, A History of American Law. 1st ed. New York: Simon \& Schuster, 1973. Pp. 655.

Lawrence M. Friedman, A History of American Law. 2d ed. New York: Simon \& Schuster, Touchstone Books, 1985. Pp. 781. \$29.95.

In 1973 Lawrence M. Friedman published A History of American Law, the first comprehensive survey of American legal history. ${ }^{1}$ The book was a monumental achievement. Just six years earlier in New York University Law School's Annual Survey of American Law, William E. Nelson had concluded that a historical chronicler of American law would not appear soon. ${ }^{2}$ An American Maitland, as he put it, needed sufficient factual information and a suitable analytical framework for assessing it. Nelson thought the latter could be constructed but the former woefully lacking. Gathering together a wide range of information drawn from an array of

Michael Grossberg is a Fellow (1987-88) at the National Humanities Center, Research Triangle Park, North Carolina. He holds appointments as associate professor of history and adjunct associate professor of law at Case Western Reserve University. Ph.D. 1979, Brandeis University.

The author would like to thank several colleagues who offered useful comments on various drafts of this essay: Carl Ubbelohde, David Hammack, and David Van Tassle. Dirk Hartog gave the piece a close reading and made several valuable suggestions. And Howard Erlanger proved a model editor in both his tolerance of delays and his timely advice.

1. Other attempts to synthesize the subject include books written by Bernard Schwartz, Law in America (New York, 1974), and Grant Gilmore, The Ages of American Law (New York, 1977). Neither rivals Friedman in scope or depth of analysis.

2. William E. Nelson \& John Phillip Reid, The Literature of American Legal History ch. 8 (New York, 1985) ("Nelson \& Reid, Literature"). This volume is a collection of the annual surveys of American legal history from their inception in 1962 to 1984. Nelson's comments were sparked by a reconsideration of Theodore Plunkett's 1930 call for an American Maitland. 
sources, Friedman revealed that more facts existed about the American legal past than Nelson might have imagined. And fittingly as a founder of the Law and Society movement and longtime advocate of the use of social science in legal analysis, he devised a compelling analytical framework to assess this material. Social science, Friedman insisted in the preface to the first edition, "gives us a way of looking at the world of law and legal history, a hope of cracking the code, a skeleton key to the horrendous mass of detail."3 The result of this marriage of fact and method rightfully won accolades as a major contribution to our understanding of American law and history. It became an indispensable guide to all those interested in the American legal past.

Twelve years later Friedman has issued a revised edition. In revision he has turned a pathbreaking book into a defiant one. Though he has incorporated much new information into the volume, "the main message is essentially unaltered." Pointedly he declares, "I have listened carefully, even respectfully, to most of my critics (not all); I have tried to keep an open mind; I throw them a bone here and there; but on the whole, to be perfectly honest, I have tended to stick to my guns. I retain the general bias set out in the preface to the first edition. Nothing since has shaken my confidence in the underlying assumptions. Work done since the early 1970 s, in the main, only confirms my stubbornness." 4

The frame of analysis to which Friedman remains committed is presented clearly in the opening pages of the first edition. Law is a reflection of society, Friedman instructs us; nothing more, nothing less. American law must be understood "not as a kingdom unto itself, not as a set of rules and concepts, not as the province of lawyers alone, but as a mirror of society." Such a depiction of law's place in society has direct consequences for Friedman's theory of historical causation: "It takes nothing as historical accident, nothing as autonomous, everything as relative and molded by economy and society." His imagery of law as a mirror frames his view of legal history as well. "The theory of this book," Friedman informs us, "is that law moves with its times and is eternally new." That pivotal assumption leads directly to the analytical heart of Friedman's method:

The basic premise of this book is that, despite a strong dash of history

3. A History of American Law 10 (New York, 1973); the preface to the first edition is also reprinted in the second. In this essay the first edition is cired as "History, 1973" and the second edition as "History, 1985."

4. History, 1973, at 15-16. Most reviewers lauded Friedman's heroic effort at synthesis; yet a persistent skepticism about his particular use of social science methodology also emerged. The most denunciatory critique came from Mark Tushnet, Perspectives on the Development of American Law: A Critical Review of Friedman's A History of American Law, 1977 Wis. L. Rev. 81-109; but see also the review by G. Edward White, 59 Va. L. Rev. 130-41 (1973), which questioned Friedman's use of social science. 
and idiosyncrasy, the strongest ingredient in American law, at any given time, is the present: current emotions, real economic interests, concrete political groups. It may seem a curious beginning to a book of history to downgrade the historical element of law. But this is not really a paradox. The history of law has meaning only if we assume that at any given time the vital portion is new and changing, form following function, not function following form. History of law is not-or should not be-a search for fossils, but a study of social development unfolding through time.

And law's functional role is not problematic for Friedman; whereas in traditional societies law consisted of divine rules that defined individual status, in "modern times" it is "an instrument" used by "people in power to push or pull toward some definite goal." In these ways the analytical image of law as a mirror, he forthrightly tells us, "is the theme of every chapter and every verse."

And so it is in the new edition as in the old. But much more so than in 1973, these analytical assumptions express, in Holmes's phrase from the Abrams decision, a disciplinary "fighting faith." Friedman has consciously and consistently clung to them in the face of searching critiques of his first edition, the emergence of competing paradigms among legal historians, and intense methodological conflicts among lawyers and historians over many of the issues embedded in his approach. Perhaps in the rare opportunity to revise an earlier work it is not surprising that an author remains wedded to an initial analytical approach. Yet on a number of counts Friedman's defiance is a bit startling and warrants inspection.

Part of the surprise comes from a rereading of Friedman's introduction to the first edition. He offered the book "not as a solution to the problems of legal history, but as a stage along the way." He called for strong reactions and held himself out as ready to have it treated as "a whipping boy." Such tentativeness is absent in the second edition. What was presented in 1973 as an initial outline written to stimulate critiques had become in 1985 a firmly etched schema for explaining American legal history.

Friedman's defiant tone is surprising as well because in the 13 years between the two editions the field of American legal history has enjoyed tremendous growth, spurred in part by Friedman himself. There are more legal historians writing now than at any time in the past; the literature in the field is far richer than it has ever been. ${ }^{6}$ Nelson's 1967 requisites for synthesis now must be reversed: the challenge facing the would-be American Maitland today is not the paucity of information but the diversity of

5. History, 1985, at 12,18, 19, 29.

6. To take one measurement, Nelson observed that more work was published in $1979-80$ than in all the years before 1960. Nelson \& Reid, Literature 304. 
interpretations. A closer look at the "underlying assumptions" that structure Friedman's new edition helps explain why A History of American Law no longer serves effectively as a scaffolding for the burgeoning field of American legal history.

\section{FRIEDMAN’S ACHIEVEMENT}

Historian Thomas Bender quite usefully tells us that " $[t]$ he appeal of any synthesis depends less on its details than on the image of society that it crystallizes in narrative form."7 The image of the American legal past that crystallizes in A History of American Law is the metaphor of law as a mirror of society. Friedman's commitment to his original framework is surely due in part to the fact that it has served him so well. ${ }^{8}$ It provides the basis for his major achievement: weaving a vast amount of information into the most compelling story of American legal history yet written.

Friedman's command of the literature of American legal history is complete. The prodigious output of legal historians since 1973 has not overwhelmed him or his analytical categories. On the contrary, he has slipped new studies into his synthesis with only minor alterations; even most of the chapter titles and subheads remain the same. As in the first edition, the history of American law according to Friedman consists of topical chapters primarily arranged in legal categories of corporations, tort, property, and the like. To these are added separate studies of legal outsiders such as women and slaves, profiles of institutional changes in the bar, courts, administrative agencies, descriptions of legal literature, and anomalies such as civil law or frontier justice. These subjects are presented in a periodized form that, after summarizing the colonial and revolutionary eras, concentrates on matched chapter assessments of each topic before and after the Civil War. The book is thus primarily a legal history of 19thcentury America. As in the first edition, the 20th century is dispatched with a cursory epilogue. Throughout, it is a history of American law that emphasizes the adaptation of private law, the bar, and legal institutions to economic change, particularly at the state level. It stresses the facilitative function of law in that process and downgrades its symbolic and repressive roles.

Generally textual changes come in the form of additional paragraphs

7. Thomas Bender, Wholes and Parts: The Need for Synthesis in American History, 73 J. Am. Hist. 122 (1986).

8. Friedman's pioneering work has made him the most productive scholar in the field. Since he began publishing in the early 1960s, he had produced an incredible number of articles and monographs. Moreover, his work has been the most thorough application of the Wisconsin approach. A listing of the publications Friedman seems to consider most relevant to the volume under review can be found in the bibliography of the second edition (History, 1985, at 715-16). 
tacked onto the existing analysis. Only a line-by-line comparison of the two editions would reveal the full extent of Friedman's revisions. But a couple of examples indicate their nature.

A typical revision occurs in the new edition's initial presentation of colonial law. While the analysis remains fundamentally the same, the argument is more pointed. In the first edition, Friedman relied on George Haskin's Law and Authority in Early New England (1960) to establish a central theme of the book: uniformity and diversity have been in constant tension in American legal history. In the colonies, Friedman argued, centrifugal and centripetal forces emerged out of material and temporal differences among the provinces, varying sources of legal rules, and recurrent efforts by imperial authorities to rationalize the system. A book published since the first edition, David Grayson Allen's In English Ways (1981), is used to buttress the same key propositions in the new edition. Friedman turns to Allen's detailed analysis of the transfer of diverse English local customary practices to New England to reinforce the original point. He weds this contention to an early assertion of Julius Goebel's, not cited in the first edition, that settlers relied on such local customs, not the law of the royal courts, to solve their problems. The combination allows him to stress two other overarching themes of the book: legal change occurs in response to local needs, and formal law is distinct from and less important than rules that people actually use. Thus an additional paragraph is placed in the narrative to clarify, not reformulate, the initial argument. ${ }^{9}$

Friedman is also willing to alter some of his contentions in light of new scholarship. The legal status of married women is a case in point. Where in the first edition he accepted the standard historical line that the colonial era was a golden age for married women, in the second he acknowledges the debate among women's historians about just how "liberal" and "enlightened" the provinces may have been. Similarly, he admits in a footnote in the second edition that recent assessments of the passage of the 19th-century married women's property acts tend "to give the women's movement more credit for the passage of the acts than the text does here." In that text, Friedman argues that the acts ought to be considered primarily as economic policies aimed at rationalizing land law and debtor/ creditor relations in response to the volatile 19th-century economy and economic needs of middle-class families. ${ }^{10}$

Revisions like these make the second edition of A History of American Law a much more thorough compendium of discrete examples of legal changes from contracts and divorce to the ICC and state bar associations.

9. This point is based on a comparison of History, 1973, at 30-32 and History, 1985, at 34-36.

10. These points are based on a comparison of History, 1973, at 184-86 and History, 1985, at 208-11. 
The additions sharpen the analytical image of law as a mirror of society used to bind the information together. They also clarify the nature of Friedman's interpretation. His analysis of the late 19th-century growth of occupational licensing is an apt illustration.

The tale is virtually identical in both editions; each draws on one of Friedman's early forays into the kind of legal history that would become his trademark, "Freedom of Contract and Occupational Licensing 1890-1910: A Legal and Social Study."1 But in the second edition, his contention that licensing ought to be recognized as the product of interest group conflicts spawned by the new professional, consumer, and health concerns of an industrial society is placed more directly within a pluralist framework. Not only does he mark off the tale with a separate subhead, it follows a more explicit statement of his thematic convictions. Thus whereas in the first edition he merely asserted that despite the rhetoric of laissez faire, significant state regulation occurred in late 19th-century America, in the second he adds a paragraph that brings his functionalist view of law into clearer focus:

In the postwar period, consensus about the issues of state aid had largely broken down; and the various actors in the struggle over law disagreed about drawing the line between the sphere of government and the sphere of free enterprise. Everybody drew a different line, but largely in accord with his own economic interests. Ideology came afterwards, as icing on the cake.

\section{Occupational licensing then becomes a "case in point." 12}

Revisions like this one make clearer what Friedman means in describing the legal system as a "blind, insensate machine. It does the bidding of those whose hands are on the controls." It reflects "the goals and polices of those who call the tune."13 Such assertions proceed directly from an analytic framework built on the assumption that in the past Americans rationally used the law as an instrument to create the kind of economy and society they desired. Despite the absence of an explicit discussion of participation, Friedman clearly believes that the law reflected what most Americans wanted even if it directly expressed the will of but a few.

This notion of rational instrumentalism leads to one last comment on Friedman's achievement in this book. Like all of the titles on Friedman's prodigious list of publications, A History of American Law is an eminently readable book. Friedman's lucid style is marked by an eye for the telling anecdote and an ability to translate complex legal rules into easily under-

11. Cal. L. Rev. 487 (1965).

12. This assessment is based on a comparison of History, 1973, at 397-405 and History, 1985 at $454-63$.

13. History, 1985, at 18; History, 1973, at 14. 
standable phrases. All of this suggests not just an accomplished writer with a congenial style, but a believer in demystification as well. Friedman clearly believes that law must not be roped off as a professional domain. If, in the parlance of political scientists like Herbert Jacob, one of the roles of law professors is to act as "gate-keepers" protecting the inner sanctum of the law from unknowing laypeople, ${ }^{14}$ Friedman is a subversive. A History of American Law, like American Law (1984) and Total Justice (1986), his most recent surveys of contemporary American law-ways, all assume the responsibility of bringing law to the people. They reveal that Friedman has the broadest vision of his audience of any practicing American legal historian.

But it ought to be noted that Friedman's determination to produce syntheses that reach beyond those in his own field has its professional costs. He appears to be quite willing to sacrifice the sophistication of presentation that accessibility requires. In the process he may also sacrifice professional standing by opening himself to detailed criticism from those in his field. Historian Thomas Haskell, who has examined the emergence of social science in late 19th-century America, reminds us that the social scientist had to "exchange general citizenship in society for membership in the community of the competent. Within his field of expertise, the worth of his opinions henceforth would be judged not by open competition with all who cared to challenge him, but by the close evaluation of his professional colleagues." 15 Friedman seems unwilling to make that exchange.

\section{THE PERILS OF ORTHODOXY}

Friedman's legal past is clear because it is rooted so firmly in his version of social science. As he says in introducing his story, social science gave him a code to decipher the mysteries of American legal history. Yet it is a tool whose limitations have become more apparent in the interval between the two volumes. The image of the law as a mirror of society enabled Friedman to write the only coherent history we have of American law. But that image is no longer the most compelling way of understanding legal history. In the end, Friedman's methodological commitments undermine the influence of A History of American Law and muddy its message.

In one sense Friedman has been overwhelmed by his own success. As he wrote in 1973: "It is a serious thing, for a branch of history, to lack a general treatment. It means there is no tradition, no received learning, no conventional wisdom." Friedman, as the synthetic voice of what was then seen as the Wisconsin school of legal history, provided American legal his-

14. Herbert Jacob, Law and Politics in the United States 9, 13, 121-51, 152-70 (Boston, 1986).

15. The Emergence of Social Science 67 (Urbana, Ill., 1977). 
tory with a powerfully enunciated statement of conventional wisdom. By doing so A History of American Law also performed the other role of orthodoxy that Friedman acknowledged: "Without convention, there is no framework, no skeleton, nothing to hang one's ideas on, nothing to attack and revise."16 The volume has served that function as well, perhaps too well for his own liking. At present there is such a range of method, interpretation, and subject among legal historians that the functionalist view of law as a mirror of society simply cannot capture the field's various images. As a framework of analysis it has suffered the perils of orthodoxy that Friedman seemed to anticipate in 1973 but resist in 1985.17

Between those dates Friedman did indeed become an orthodox voice of American legal history. Of course, neither he nor his methods started out that way. Coming out in the $1950 \mathrm{~s}$, but rooted in conflicts and social thought of the 1930s and 1940s that produced modern liberalism and Parsonian functionalist sociology, a group of social-science-inclined lawyers reoriented legal history. Led by Willard Hurst, the most influential historian of his generation, they turned the University of Wisconsin into the birthplace of a new legal history. At Wisconsin empirical methods and behaviorist theories were marshaled to study the legal response to economic change. The proper topics of analysis became market activities in the localities of the past and the private law of economic relations. The proper methods were interest group analysis, quantified assessments of trial records, and rational actor models. This union of topic and method emerged from a social science approach that aped the natural science ideal of verifiable truth. Out of this reorientation came the first major version of American legal history. It advanced an historically coherent view of law as a rational instrument that could be seized by members of the dominant middle class to achieve consensual economic goals. The analytical image of the law as a mirror of society best captured the substance and method of this Wisconsin legal history. ${ }^{18}$

Key tenets of the functionalist orthodoxy have been under attack since the mid-1970s. Even the legal history coming out of Wisconsin ceased to represent a unified school as Robert Gordon, Mark Tushnet, and Hendrik Hartog deviated in various ways from Hurst, Friedman, and

16. History, 1973 , at 9 .

17. Nelson describes the shifts in the field by suggesting that "the discipline of American legal history has changed in recent decades from one in which nearly all scholars in the field shared a common sense of purpose to a field in which different scholars pursue quite different ends." Nelson \& Reid, Literature 303. For his general assessment of this development and its consequences see id. at ch. 17.

18. For helpful assessments of the Hurst approach see Robert Gordon, J. Willard Hurst and the Common Law Tradition in American Legal Historiography, 10 Law \& Soc'y Rev. 9 (1975); Stephen Diamond, Legal Realism and the Historical Method: J. W. Hurst and American Legal History, 77 Mich. L. Rev. 784-94 (1979); Review Symposium: The Work of J. Willard Hurst, 1985 A.B.F. Res. J. 113-44. 
each other. Friedman has read the critics. In a quasi-autobiographical 1983 article, he offered a thoughtful reply that gives some perspective to the methodological approach he reiterated two years later in the second edition of A History of American Law.

Friedman recaptured the excitement of being a Hurstian in the 1950s and 1960 s. He remembered himself as a warrior doing "a necessary job of destruction-entering the lists against the old non-social, non-quantitive, doctrinal history, all of which struck me as so old-fashioned, so arid, so . . . establishment." It was thus with a sense of shock that he found himself part of an orthodoxy; the "Hurst school was now in the front line, ready to be ripped apart by a new generation." He catalogued the critiques: functionalism, defense of the status quo, treatment of law as only a dependent variable, tendencies toward economic determinism, downgrading the role of ideology in law, overdependence on empiricism, obsession with market relations at the expense of social ones, and a reluctance to recognize symbolic as well as instrumental uses of law. Friedman conceded that each criticism had some validity. In particular, he acknowledged that by refusing to grant the law a degree of autonomy, functionalist Wisconsin legal historians downgraded the importance of law in American society; they tended to deny that "there is any special quality about law and legal institutions."' 9

Friedman depicted the conflicts among legal historians as a joust between the Hurstians and advocates of Critical Legal Studies, whom he also labels "neodoctrinalist" to link them back to his original foes. Part of the disagreement between the two he attributes to political persuasion: "it is true that Wisconsin people, politically speaking, tend to be moderates and New Dealers, not Marxists or radicals." The rest results from subject and method: doctrine versus law in action; theory versus empiricism. He argues that these differences proceed from clashing notions of the fairness and justice of American society, past and present, and disagreements over the law's role: Was it ideological and symbolic, used to legitimize repression and hierarchy? Or instrumental, wielded to achieve economic expansion and individual liberty? ${ }^{20}$

The second edition of A History of American Law ought to be taken as Friedman's most sustained response to the critiques of the Hurstian approach. There are modifications, caveats, and concessions in the book.

19. The State of American Legal History, 17 Hist. Teacher 107, 110 (1983). Of course, Friedman does not speak for all of those in the Hurst tradition, which has produced a varied group of scholars. The work of historian Harry N. Scheiber is most divergent from key elements in Friedman's orthodox Wisconsin approach. See, e.g., his call to retrieve American constitutional history, a casualty of the private law focus on most Hurstians, American Constitutional History and the New Legal History: Complementary Themes in Two Modes, 68 J. Am. Hist. 337-50 (1981).

20. Friedman, 17 Hist. Teacher, at 110. 
But as he says in the preface, on the major issues he has read and rejected his critics. The book is thus as well the most comprehensive statement of the orthodox functionalist position. It is studded with additions that question the role of ideology, that belittle the significance of doctrine, and that reemphasize the reflective nature of the legal system. But the debate is broader than the one Friedman acknowledges. ${ }^{21}$ The issues raised by Friedman's reassertion of the functionalist approach relate not just to disagreements among specialists in the legal history; they touch upon some of the most important debates among all historians. A fundamental reevaluation of the nature and use of social science methods is occurring throughout the discipline. It has been sparked by a growing disenchantment with the kind of social science approach represented in legal history by the functionalist school. ${ }^{22}$ Two issues, republicanism and slavery, illustrate how Friedman's analytical assumptions unfortunately limit the integration of his legal history with other bodies of historical scholarship that might have enriched his story.

\section{Republicanism and Intellectual History}

Ideas play a very minor role in the life of the law in A History of American Law. In the 1983 article, Friedman admitted that Hurst and his follow-

21. He does note that some legal historians (he mentions Nelson, John Reid, Robert Gordon, and Michael Hindus) do not fall within either the Hurst School or the Critical one. Id. at $108-9$.

22. This disenchantment is perhaps most vividly presented in calls for the return of the narrative to history writing. Indeed, Lawrence Stone's plea for the narrative has become a signal event in the discipline because he had so fervently championed a social-science-dominated historical methodology; The Revival of Narrative: Reflections on a New Old History, 85 Past \& Present 3-24 (1979). Similarly, in a recent assessment of social history, Olivier Zunz voiced the widely held view: "Social historians should now begin to free themselves from the theories of social scientists and use the vast accumulation of historical social description to generate their own theories. Greater independence from social science will also make it easier for social historians to integrate their findings with those of political and economic historians and build sound explanatory frameworks. It will also permit the links between intellectual and social trends to be more readily perceived. Understanding how ideas contribute to the course of history is as crucial as understanding how history shapes ideas." The Synthesis of Social Change: Reflections on American Social History, in Zunz, ed., Reliving the Past: The Worlds of Social History 100 (Chapel Hill, N.C., 1985) ("Zunz, Synthesis of Change"). See, e.g., Scheiber, 68 J. Am. Hist., at 338 (cited in note 19), for a discussion of similar developments in political science. Attacks on Friedman's use of social science methods are hardly new to him. As early as 1965 , New York University legal historian John Reid took Friedman to task for his "behaviorist interpretation" in the article on occupational licensing cited in note 11; saying that Friedman was a young man, Reid paternalistically suggested that if "he can discipline himself to avoid such speculations, he may have something to contribute to American legal history in the years to come." Nelson \& Reid, Literature 81-82 (cited in note 2). Such criticism did not daunt Friedman, and clearly he has had a lot to contribute to American legal history. But now the skepticism among historians is much greater than when Reid chided him. 
ers have "downplayed the inner life of the law, its intellectual roots." 23 Though consistent with his functionalist predilections, Friedman's undervaluing of the importance of ideas in American law-especially legal thought itself-is one of the most troubling aspects of the book; and revision has only made it more so as his explanation of law in the Revolutionary era demonstrates.

The role of ideology in the Revolution and its aftermath has been one of the most important and hotly debated topics among American historians. Couched in terms of the saliency of republicanism as a coherent set of beliefs that structured the most fundamental conflicts and results of the Revolution, the debate has had profound implications for our understanding of all aspects of American society in the era. Republicanism has served dual purposes: it has become the primary way historians explain the thought and beliefs of the revolutionary generation; it has become a testing ground for historical analysis of the way ideas enter into the making of events. Each use of republicanism has had a profound impact on the discipline. ${ }^{24}$

On the occasion of the bicentennial of the constitution, a recent issue of the William and Mary Quarterly devoted its forum pages to a reappraisal of one of the most important works that launched the struggle to understand republicanism, Gordon S. Wood's The Creation of the American Republic, 1776-1787 (1969). Each of the 12 contributors begins his or her article by emphasizing the importance of Wood's book to a full understanding of the revolutionary period. According to historian Pauline Maier, "Articles or books written on that topic without coming to terms with Wood are, as Tom Paine said in another context, like almanacs of yesterday." 25 Not only does A History of American Law fail to address or even footnote Wood's book, it sidesteps the whole debate by relentlessly employing a functionalist approach that denigrates the importance of ideology and relies on instrumentalism to explain the legal and constitutional changes of the period.

Friedman argues that in the Revolutionary era American law became a unique blend of colonial traditions, English borrowings, civil law relics, and postrevolutionary innovations. He deftly summarizes the intricate literature over old legal history chestnuts such as reception of the common law and the movement to ban the use of English law. Fights over these issues, like most contests over the content of the law, were, he thinks, resolved in a utilitarian manner by placing use over theory, interest over ideology. In a typical assessment, he contends that postrevolutionary An-

23. 17 Hist. Teacher, at 106.

24. Joyce Appleby, Republicanism and Ideology, 37 Am. Q. $462-63$ (1985).

25. Pauline Maier, A Pearl in a Gnarled Shell: Gordon S. Wood's The Creation of the American Republic Reconsidered, 44 W/m. \& Mary Q. 583 (1987); the entire forum on Wood's book, which includes a reaction by Wood himself, occupies pp. 549-640. 
glophobia could not dislodge English legal forms because the "habits of a lifetime were not easily overthrown, despite ideology." Thus, the legal choices of the founding era were the product of a broad agreement on needs and interests, not an "idle exercise in political theory." The function of law ceased to be the colonial one of order and became "economic growth and service to its users." He makes the point directly: "In this period, people came to see law, more and more, as a utilitarian tool: a way to protect property and the established order, of course, but beyond that, to further the interests of the middle-class mass, to foster growth, to release and harness the energy latent in the commonwealth." And then he quotes Hurst: "Dynamic property rather than static property, property in motion or at risk rather than property secure and at rest."26 The final line from Hurst establishes that the primary legal triumph of the founding era was an instrumental use of law; henceforth the effectiveness and legitimacy of the law would be determined by its utility in forging a vibrant economy.

Throughout this analysis of the founding era run Friedman's central themes. The newly created legal order was the product of interest group conflicts. Thought and action, formal and applied law were actual dualities. Rationalism and clearly articulated consensual goals, not legal thought, guided legal actions. The law itself was a neutral force wielded by various groups within an ideological consensus so fundamental, and continuous, that it need not be explained. Typically postrevolutionary efforts at delegalization are dismissed as mere utopianism, and the urge to reform the law reduced to an inevitable effort at "adaptation to the needs of a market economy." In short, from Friedman we have a view of Americans during the founding era as pragmatic relativists who held the same conceptions of their interests and needs as would their descendants. ${ }^{27}$

Friedman's commitment to this view is evident in his unwillingness to make political labels timebound. He classifies constitutional revision in Pennsylvania as a tale of "advanced liberalism" in 1776, "conservatism" in 1790 , and "moderation" in 1838 without defining any of these terms; we all are assumed to know the frame of reference. The meanings simply do not change over time; change occurs as altered material conditions require new uses of law. Ideas are rendered superfluous or mere rationalizations of interests to be cast aside when those interests change. ${ }^{28}$

The major difficulty with this synthetic image is that it flattens all the hard edges of conflict in the period. Indeed, it denies our own distance from this seemingly accessible past. Friedman leaves little room for the contingencies, ambiguities, and uncertainties, let alone fundamental disagreements, most historians find in the Revolutionary era. His instrumen-

26. History, 1973, at 107, 111, 112, 114, 115.

27. Id. at $113,117$.

28. History, 1973, at 113,117 . 
talism robs law and legal institutions of their significance, even though students of the founding era's political thought tell us about the inextricable interconnections of legalism and republicanism. ${ }^{29}$ His analytical commitments simply prevent him from treating ideology seriously.

Yet doing precisely that-taking ideas seriously-has produced the most important recent insights on the founding era. Dissatisfaction with prevailing pragmatic and instrumental explanations of the era arose in part in response to the tendency of historians like Friedman to consider ideas as unproblematic elements in the minds of the Revolutionary generation. The depiction of people "choosing ideas much as they bought and sold in the free market, according to the value received" ceased to be a compelling explanation of the era's deep ideological commitments as did its rationalistic assumptions about the life of the mind. ${ }^{30}$ Historians found in republicanism a way to understand the intellectual universe of Revolutionary America that addressed the interplay of belief and behavior instead of assuming the former a mere product of the latter. Now dubbed the "republican synthesis," the ideology of republicanism has become a thematic device for examining the relationship between political thought and economic and political developments in the era as well as for probing their long-term consequences. "Republicanism," Wood tells us in suggesting its analytical lure, "meant more for Americans than simply the elimination of a king and the institution of an elective system. It added a moral dimension, a utopian depth, to the political separation from England-a depth that involved the very character of their society." 31

Briefly stated, republican ideology posited fundamentally connected social beings, politically independent through their ownership of property, capable of placing the common welfare before their private interests, and upon whose civic virtue depended the existence of a republic of mixed and balanced powers. It was at once a political, economic, and social creed with various strains. In its purest form (denominated "civic humanism" or "classical republicanism") it represented an intellectual yearning for a "return" to traditional, precommercial values that were supposed to characterize an uncorrupted American society. Other strains of republicanism emphasized egalitarianism and communalism and either embraced or decried the new capitalist spirit. Historian Robert Shallope notes:

These divergent views were rooted in experiences and values. Every-

29. See in particular Wood, The Ambiguity of American Law, in The Creation of the American Republic ch. 24 (Chapel Hill, N.C. 1969) ("Wood, Creation"); and Hendrik Hartog, Distancing Oneself from the Eighteenth Century: A Commentary on Changing Pictures of American Legal History, in Hartog, ed., Law in the Revolution and the Revolution in Law 229-57 (New York, 1981).

30. Appleby, $37 \mathrm{Am}$. Q. at 463.

31. Wood, Creation 47. 
one desired some reformation from the Revolution, but, depending on an individual's position in society, each drew on republican theory selectively. While all saw England as a threat, Americans ranged from radical to conservative in their views about how to confront that threat and in their hopes for the future. ${ }^{32}$

In the hands of historians like Wood, republicanism in its many variations makes comprehensible central legal developments of the era, such as popular sovereignty and federalism. It has helped decipher the ideological assumptions that structured the struggles that gave such concepts meaning and utility. To rephrase Friedman, the import of this work is that in many cases function did indeed follow form. Moreover, the relationship of republican political thought to contemporary social and economic changethe links of thought and action-have become the central issues of historical analysis. More and more historians have come to conclude that the late 18 th and early 19 th centuries were years of fundamental change marked not only by the creation of a new political ideology but also by the triumphal emergence of liberalism as the basis of social relations and market capitalism as the primary form of economic production and exchange. In doing so, they emphasize the interrelationship of these phenomena and the long-term consequences of the era in law as in other parts of society. ${ }^{33}$

Though a lively debate rages about the exact nature and implications of republicanism, reclaiming it, historian Linda Kerber tell us, "owes much to an enlarged sensitivity to and respect for words as carriers of culture, and to a respect for ideology as an authentic expression of political situation and cultural condition." 34 It is precisely these sensitivities that are absent in A History of American Law.

Friedman's methodological approach forces him to discount contemporary dialogues, especially his sharp separation between belief and behavior, ideas and action. Intellectual historians of the period, on the other hand, are intent on uncovering the particular constellation of convictions that various groups of people relied upon to understand their world. In using republicanism to understand the nature of language and consciousness, political thought and belief have come to be considered mediums

32. Shallope, Toward a Republican Synthesis: The Emergence of an Understanding of Republicanism in American Historiography, 29 Wm. \& Mary Q. 49 (1972). The seminal books that launched the attempt to recover republicanism include Wood's volume, that of his mentor, Bernard Bailyn, The Ideological Origins of the American Revolution (Cambridge, Mass., 1967), and the work of J. G. A. Pocock, especially The Machiavellian Moment: Florentine Republican Thought and the Atlantic Republican Tradition (Princeton, N.J., 1975).

33. Edward Countryman, Of Republicanism, Capitalism, and the "American Mind," $44 \mathrm{Wm}$. \& Mary Q. 559 (1987); for a useful introduction to the debate on republicanism see the articles in Republicanism in the History and Historiography of the United States, 37 Am. Q. 461-598 (1985).

34. The Republican Ideology of the Revolutionary Generation, 37 Am. Q. 474 (1985). 
through which men and women interpreted their interests. Instead of thought being a mere product of interests, historian Joyce Appleby asserts, ideas are now assumed to "intervene and mediate between circumstances and responses to those circumstances." At the same time, she adds, the reigning conviction that republicanism stood as an interpretive framework that helped determine political affirmations has forced a reassessment of the place accorded individual choices: "Where the decision-making individual once stood at the center of our analysis of politics, ideology has pushed to the fore social forces that presumably have shaped the consciousness of the individuals we study." 35 In sum, as Wood reminds us, "[i]deas are a constant of human behavior; they may not cause us to behave as we do, but we do not behave without them." That methodological faith, so different from Friedman's, enabled him (and others) to recapture the broad-gauged debate in the era. ${ }^{36}$

By reducing the law to a mere instrument Friedman cannot make room for republicanism in any of its forms. He presents us with results, like the American fetish for constitutions and the distinctive American notion of judicial independence, without their ideological moorings. Intellectual historians of the era, though, argue that such results are simply not comprehensible without an understanding of their sources in the political thought of the era. This difference, rooted in clashing notions of causation and the nature of change itself, leads to fundamentally different visions of the revolutionary period. Instead of liberating law to be a politically neutral utilitarian instrument as Friedman insists, proponents of the republican synthesis suggest that the changes of the era encased the law in new political and ideological structures that conditioned its use and users. In the new formulation the legal system thus becomes a purveyor of values, not merely a set of mediating and adjusting institutions.

In his critique of critical legal studies, Friedman questions the crits' dismissal of the instrumental role of law. Surely he is right to argue: "No symbol, no myth, no legitimator can last in this society, without at least some instrumental function or base. One ignores the data at the cost of falsifying the historical record." ${ }^{37}$ But the reverse is equally true. Unable to conceive of law in the Revolutionary era as a major arena of struggle

35. Appleby, 37 Am. Q. at 462.

36. Wood, Ideology and the Origins of Liberal America, $44 \mathrm{Wm}$. \& Mary Q. 629 (1987). For a discussion of the relationship of the scholarship on republicanism to larger movements in intellectual history see Robert Darton, Intellectual and Cultural History, in Michael Kammen, ed., The Past Before Use: Contemporary Writing in American History, 327-54, esp. 343-44 (Ithaca, N.Y., 1980) ("Kammen, Past"); for a recent example of these methods applied in legal history see Stephen Conrad, Polite Foundation: Citizenship and Common Sense in James Wilson's Republican Theory, 1984 Sup. Ct. Rev. 359-88.

37. Friedman, 17 Hist. Teacher, ar 113 (his emphasis). The difficulties of integrating republicanism into a larger analytical approach ought not be minimized, however. For a critique of my use of the term see Emily Field Van Tassel, Judicial Patriarchy and Republican Family Law, 74 Geo. L. Rev. 1567 (1986). 
instead of a normative void, he gives us the structure without an understanding of the conflicts that produced it and continued to dominate its use. Too many major issues are assumed away by functionalist assertions that choices were made outside, not inside, the law and rules were mere implementations of those choices. Thus we are left with little understanding of why, in this critical era, law was such an appealing instrument to so many newly christened Americans.

\section{Slavery and Social History}

Friedman's dismissal of ideology may well originate in his classification of his book as a "social history." 38 Though the term is never directly defined, social history seems to be Friedman's means of identifying his primary subject: the development of a distinctive American legal culture. Since his functionalist predilections dictate that use, not theory, must be the central reality of that culture, Friedman's social history is an attempt to uncover the social context of legal instrumentalism. Much of his conception of social history derives from his jousts as a Hurstian with an earlier tradition in legal history that abhorred social science methods, ignored trial courts, and studied only doctrine and public law. The Critical Legal Studies movement, with its fascination with doctrine as evidence of ideology, has clearly reignited his concerns. Most important, though he shares some common impulses with contemporary American social historians, especially an interest in non-elites and everyday life, Friedman's attempt to use social history to identify the creation and elaboration of an American legal culture is stymied by his inattention to a vigorous debate that rages outside the law school walls.

After two decades of dominating American historical scholarship, social history is itself in disarray. Controversies abound over method and meaning. Two aspects of the debate are particularly relevant to an assessment of Friedman's approach. First, there is a growing disenchantment among social historians with now conventional social science methods, particularly the forms of empiricism that so dominated the new social history as it emerged in the 1960s. In order to uncover the lives of the "inarticulate," as social historians defined the study of such non-elites as women, slaves, and working people, the "first generation of social historians was willing to accept the hegemony of the social sciences." 39 Quantifi-

38. History, 1973, at 12. For an earlier attempt to define a social history of American law, one much like Friedman's, see Richard B. Morris, The Courts, the Law, and Social History, in Morris N. Forosch, Essays in Legal History in Honor of Felix Frankfurter 409-22 (Indianapolis, 1966).

39. Zunz, Synthesis of Change (cited in note 22). Typical of the era was French historian Emmanuel Le Roy Ladurie's declaration: "Tomorrow's historian will program computers or will cease to exist." The Territory of the Historian 14 (trans. Chicago, 1979). 
cation, in particular, seemed to confer a long-sought scientific certainty to historical generalization. Demographic techniques, forms of modernization theory, sociological models of stratification, and theories like Tönnes's gemeinschaft/gesellschaft dichotomy dominated the work of these historians. Disillusionment with the ahistorical nature of those methods has grown. Historian Harold Woodman has voiced these concerns in a particularly evocative manner: "one of the ironies of modern historical scholarship [is] that historians in rejecting as impossible the notion that they simply tell things as they happened and in recognizing instead the need for an organizing theory to give meaning to their work, so often turn to static theories from the social sciences. Whatever their value for economists, sociologists, and political scientists, these theories have but limited value for historians because social science theories are timebound, or, to put the point in another way, such theories usually assume the very matters that historians seek to investigate."40

Disenchantment has not usually meant the rejection of social science-particularly not quantification-but, rather, a search for new methods that can uncover the culture and ideology of social groups in the past. ${ }^{41}$ Social historians have turned to more subjective approaches that take culture more seriously such as the descriptive techniques of cultural anthropologist Clifford Geertz, the work on cultural hegemony by Marxist theorist Antonio Gramsci, and the new methods of literary analysis such as hermeneutics and deconstruction. ${ }^{42}$

Second, and directly related to the first point, more sophisticated conceptions have emerged of the people social historians study and the questions about them to be answered. Social history burst out in the 1960s with a "populist bias," a "feeling that ordinary people are responsible for their own history." 43 Demographic techniques translated into community studies became the primary method of finding those histories. Yet, despite a wealth of information on geographic mobility patterns, fertility

40. Harold Woodman, Preface in Elizabeth Fox-Genovese \& Eugene D. Genovese, The Fruits of Merchant Capital: Slavery and Bourgeois Property in the Rise and Expansion of Capitalism xviii (New York, 1983) ("Genoveses, Fruits").

41. This has been in part an implicit recognition of what the Genoveses call the "political crisis of social history"; by that they mean the inability of social historians to integrate political power and public institutions into their analyses. Genoveses, Fruits 7; Bender, $73 \mathrm{~J}$. Am. Hist. 123-32 (cited in note 7).

42. For general discussions of these issues see Zunz, Synthesis of Change (cited in note 22), and Peter N. Stearns, Toward a Wider Vision: Trends in Social History, in Kammen, Past, at 205-30 (cited in note 36) ("Stearns, Toward a Wider Vision"). Stearns, in particular, makes the point that the methodological controversies among social historians are not merely repeats of earlier debates over the value of quantification but are rather more fundamental inquiries into the notion of social analysis itself: "Certainly, issues remain to be debated, related to but broader than the choice of quantitative or qualitative emphasis. The concern for outlook or mental attitude relates social historians not only to cultural but also to psychological theory, in intent if not usually in conceptional arsenal." Stearns, id. at 229.

43. Zunz, Synthesis of Change 58. 
rates, and occupational stratification, the essence of group culture eluded historians. The inability to capture fully the lives of the groups they studied has led social historians to the conclusion that much more than a rendition of vital statistics is needed to uncover group identity, place, and impact. These conclusions have been fueled by a growing "belief in at least semi-independent, identifiable subcultures that allow popular groups some independent basis for reaction to larger systems and processes." 44 Women factory workers, urban workers, slaves, professionalizing teachers, and a variety of other groups have been examined in this way, in an effort to find the nature of each subculture and its relation to the values and power of other groups.

By breaking down the formerly monolithic notion of American society into contending groups with varying voices, social historians have also begun to address issues of power often ignored under the dominion of supposedly apolitical social science methods. Reversing the "depolitization of social history" has reinforced interest in exploring forms of past reality less susceptible to empirical measurement. As historian T. Jackson Lears has observed: "The whole debate over falsifiability often seems to rest on the empiricist fallacy that what cannot be precisely observed and measured does not exist. The empiricist tradition can check dogmatic assertion but also impoverish historical imagination." 45 Indeed, today, a conception of past American societies as collections of quasi-autonomous groups of varying political and economic strength and holding a range of common and distinct beliefs dominates the vision of social history. Neither of these tendencies in the writing of American social history is apparent in the second edition of A History of American Law.

Consider the history of slavery in antebellum America. In their critique of the apolitical nature of so much recent social history, Elizabeth Fox-Genovese and Eugene Genovese, pre-eminent historians of slavery, convincingly argue that there can be "no worthwhile social history that is not informed by theory-by a coherent interpretation of social process in general and political economy in particular." 46 Such a criticism cannot be

44. Stearns, Toward a Wider Vision.

45. Lears advocates that social historians turn to Gramsci because the concept of cultural hegemony can aid "social historians seeking to reconcile the apparent contradiction between the power wielded by dominant groups and the relative cultural autonomy of subordinate groups whom they victimize. T. Jackson Lears, The Concept of Cultural Hegemony: Problems and Possibilities, 90 Am. Hist. Rev. 568 (1985); and for a related argument cast in terms of legal history see Peter Linebaugh, (Marxist) Social History and (Conservative) Legal History: A Reply to Professor Langbein, 60 N.Y.U. L. Rev. 212-43 (1985). For examples of the social history mentioned in the text see Perer Dublin, Women at Work: The Transformation of Work and Community in Lowell, Massachusetts, 1826-1860 (New York, 1979); Sean Wilentz, Chants Democratic: New York City and the Rise of the American Working Class, 1788-1850 (New York, 1984); Paul Mattingly, The Classless Profession: American Schoolmen in the Nineteenth Century (New York, 1975). 46. Genoveses, Fruits 198 (cited in note 40). 
made of A History of American Law; rather, the problem is that Friedman's particular theory of social history blocks his effective use of the social history of slavery. As is the case with the historiography of republicanism produced by intellectual historians, Friedman's often compelling synthesis of slave law suffers from its inattention to debates among social historians.

Nevertheless, he offers a nuanced account of slave legal doctrine. The obvious role racism plays in slave law checks his tendency toward economic determinism: "In some ways, economic motives seem too flaccid to explain the Southern passion about race." He describes the main categories of race law: increasingly rigid rules governing manumission and emancipation; the special black codes north and south that governed free blacks; and specific southern code laws devised to regulate slavery itself. He makes the sources of these rules clear: "Of course, the laws governing slavery-the slave codes of the South-were not responsible for social attitudes. On the contrary, race feelings, whatever their psychic or economic background, helped write the codes." Such assertions carry his dominant imagery of the law as mirror into the domain of slavery.

Friedman also enters one major debate in the legal history of slavery, the role of appellate courts. Political scientist A. E. Keir Nash has argued that appellate judges struggled to treat black slaves fairly by trying to enforce statutory rights such as protection against a master's cruelty. Friedman notes the existence of slave rights on the books but questions their actual utility for blacks. He relegates appellate decisions dealing with slaves to the marginal place he reserves for all doctrine. "Anyone with praise for Southern justice, at the formal level," he insists, "has to bear in mind what plantation justice was like." Economic self-interest, not legal rights, protected slaves. The focus of his discussion of slave law is on its marginality; the fuss about understanding the slave rights written in lawbooks, he asserts, is much ado about nothing: "these rights gave Southern law an appearance of justice, an appearance of fairness, which the slaveholding class valued greatly. At the same time, there was no way the enforcement of rights could threaten the real social order." 47

Yet what was that real social order? Why were slaveholders concerned with legal appearance at all? Indeed, might southern law be more than a mere label? These are the sorts of questions that Friedman's analysis begs. And they are precisely the kinds of questions being asked by social historians. Whatever their differences, and there are many, social

47. History, 1973, at 226; and for Friedman's comments on the issue of economic determinism see Friedman, 17 Hist. Teacher, at 110-11 (cited in note 19). For Nash's argument see his articles A More Equitable Past? Southern Supreme Courts and the Protection of the Antebellum Negro, 48 N.C.L. Rev. 197 (1970); id., Reason of Slavery: Understanding the Judicial Role in the Peculiar Institution, 32 Vand. L. Rev. 7 (1979); id., In re Radical Interpretations of American Law: The Relationship of Law and History, 82 Mich. L. Rev. 274-345 (1983). 
historians unite in the conviction that social history must capture the experiences of various groups, particularly non-elites. In works such as John Blassingame's The Slave Community (1972) and Genovese's Roll, Jordan, Roll: The World the Slaves Made (1974), social historians have recovered the reciprocal nature of the master/slave relationship. Out of an understanding that the power of masters was not absolute and that slaves exerted their own forms of authority among themselves and with their masters, a distinctive slave subculture has been located. Related studies by historians such as Bertram Wyatt-Brown and James Oakes have tried to do the same for other features of southern culture. ${ }^{48}$ By granting various groups their own vision of reality and their own sense of their interests, social historians have created an interactive model of past relations. And most important here, legal sources have been one of the major means of developing these arguments. In the hands of historians like Genovese and Wyatt-Brown, judicial decisions, codes, and customary legal behavior have been used to understand critical components of the slave and free worlds of the antebellum South.

In contrast, Friedman's social history of slave law seems too bound to formal legal categories. There is little attempt to capture the experiential reality of race law; instead the analysis denies slaves any mediating power in the law. Rather than analyzing the law as one mode of structuring a complex relationship, as social historians have, Friedman presents it as an unproblematic instrument of repression. Social history encourages us to study formal legal rules as but one part of the role of law in society, as translations and as mediations of aspirations and claims, but not the end of the inquiry. We must go on to an understanding of the law and slavery that recognizes that slave and master had to take account of one another's full range of beliefs, feelings, and personal interests. And until we do so, the boundaries between realms of the legal and the nonlegal will never be clear. ${ }^{49}$

Locating forms of legal consciousness is where social history sends us. The study of slavery has encouraged two forms of historical exploration. First, the competing legal consciousnesses among Southerners themselves, slave and free, has begun to be examined. Instead of positing that southern whites placed protection for slaves in the codes as mere window dressing because they wanted a public image of the law as fair and just, Nash, Mark Tushnet, Thomas Morris, and others have tried to determine the view of law and society embedded in such efforts. They have found not just instrumental uses of law to conceal repression, but also conflicting

48. Bertram Wyatt-Brown, Southern Honor: Ethics and Behavior in the Old South (New York, 1982); James Oakes, The Ruling Race: A History of American Slaveholders (New York, 1982).

49. On this point see William Forbath, Hendrik Hartog, \& Martha Minow, Introduction: Legal Histories from Below, 1985 Wis. L. Rev. 759-66; Genoveses, Fruits 370. 
commitments among judges, lawyers, legislators, slaveholders, and other free Southerners over such legal rights. Morris argues: "The recognition of social hierarchy, not just market calculations, did play a role in the way jurists dealt with contracts to mortgage or sell slaves. A paternalistic social system grounded upon the ownership of human beings did find expression in the courts that would protect whites in some cases at least from being dealt with as if they were as powerless as slaves. Such a world view, however, lived in uneasy alliance with a market individualism that was seeping into the cases involving contracts for the transfer of slaves."50 Similarly, Genovese and others have begun to sketch slave views of various forms of law from formal codes to customary practices. Friedman hints at this complexity by juxtaposing formal slave codes to plantation justice and customary practices, but he makes no attempt to probe the implications of these forms for slave culture. Social historians have; in his history of the black family, Herbert Gutman quotes the oral recollection of marriage law by a former slave: "God made marriage, but da white man made de law."51 Embedded in such a declaration is a particular legal consciousness that must be made the stuff of the social history of American law.

Second, historian of slave law posit the existence of fundamental regional distinctions in antebellum law. Genovese's views are particularly significant because of all social historians of slavery he has woven legal history most thoroughly into the fabric of his analysis. His conclusion is clear: once "slavery assumed a commanding position in southern society, it redirected the legal system as whole." ${ }_{52}$ But Genovese's is not a functionalist argument. On the contrary, he discovers the importance of law in slavery only by treating it as a semi-autonomous realm within southern society and, in turn, the larger nation. Likewise, instead of discounting the importance of regionalism as does Friedman, other legal historians argue that significant regional distinctions emerged in the law. They locate its uniqueness in the cultural matrix of a distinctive southern society that contained regional variations of national economic, social, and political

50. "Society Is Nor Marked by Punctuality in the Payment of Debt": The Chattel Mortgage of Slaves, in David J. Bodenhamer \& James W. Ely, Jr., eds., The Ambivalent Legacy 160 (Jackson, Miss., 1984) ("Bodenhamer \& Ely, eds."); Mark Tushnet, The American Law of Slavery, 1810-1860: Considerations of Humanity and Interest (Princeton, N.J., 1981); Paul Finkelman, An Imperfect Union: Slavery, Federalism, and Comity (Chapel Hill, N.C., 1981) ("Finkelman, Imperfect Union"); and Nash, 32 Vand. L. Rev., at 49 (cited in note 47).

51. Gutman, The Black Family in Slavery and Freedom 284 (New York, 1976). And see James Oakes, From Republicanism to Liberalism: Ideological Change and the Crisis of the Old South, $37 \mathrm{Am}$. Q. 569-70 (1987), for an effort to link changes in republicanism to the beliefs of white yeomen and black slaves.

52. Genoveses, Fruits 365; and see Eugene D. Genovese, Roll, Jordan, Roll 25-49 (New York, 1974). For a critique of Genovese's approach see John Patrick Diggins, Comrades and Citizens: New Mythologies in American Historiography, 90 Am. Hist. Rev. 616 (1985). 
forms. ${ }^{53}$

It is the very emphasis on legal culture, a crucial category to Friedman, that suggests the larger importance of the legal history of slavery and the issue of regionalism it raises. Most studies of slaves law suggest that we must conceive of legal culture as comprising the central beliefs, values, and meaning that various groups of people hold and which affect the way in which they organize their institutions and relations-among themselves, between themselves, and among institutions. As such, regional legal cultures had a determining effect upon the nature of socially constructed institutions, their agents, and members. The specific features of a legal culture are difficult to disentangle, as legal anthropology makes clear, and they relate to each other in complex ways. They are the stuff, of course, of interpretation, disagreement, and conflict. But they cannot be analyzed at all if methodological assumptions conceal the problems of historical particularity and change. Much of the history of slave law, thus challenges the implicit argument advanced by Friedman that southern legal differences were merely regional variants of a modernizing society, a stage that would inevitably prove dysfunctional. He was more explicit about the point in an article on the subject: "Differences among regions tended to be differences in timing, pace, and manner, not differences in fundamentals." 54 Most historians of slave law disagree with the assumptions of that conclusion. Notions of inevitable regional convergence and uniform paths of development-corollaries of modernization theory-obscure the reality of significant cultural differences among American regions at particular times and with particular results. The challenge is to identify the nature and implications of regional legal distinctiveness and do so in a manner that allows for change over time. ${ }^{55}$

"Slave law," Friedman tells us, "had its own inner logic." Yet that logic eludes Friedman. It can be discovered only by taking the law seriously, by granting it some sort of integrity and autonomy, some place in the minds of free and slave Southerners. Slave law must then be connected to the logic, the integrity, and autonomy of other aspects of the

53. E.g., see the articles collected in Bodenhamer \& Ely, eds. (cited in note 50); and see the pieces by Paul Finkelman and William Wiecek in the forthcoming proceedings of a March 1987 conference on "The South and the American Constitutional Tradition," held at the University of Florida. For an adherent of the Wisconsin school who gives greater credence to regional differences see Harry N. Scheiber, Xenophobia and Parochialism in the History of the American Legal Process, 23 Wm. \& Mary L. Rev. 625-61 (1982); id., Federalism, the Southern Regional Economy, and Public Policy Since 1865," in Bodenhamer \& Ely, eds,. at 69-105.

54. The Law Between the States, in Bodenhamer \& Ely, eds., at 42; for a more complete discussion of Friedman's views on legal culture see Total Justice 38-43, 97-101 (New York, 1985).

55. For a discussion of these methodological issues in a larger North American context, see Michael A. Goldberg \& John Mercer, The Myth of the North American City: Continentalism Challenged (Vancouver, Can.: 1986). 
larger national legal culture. Friedman informs us that slave law's "object was repression and control" and that "[e]verything tended toward that end." 56 But the social history of slavery suggests a more complicated picture, one that indicates how we might understand slave law more fully and use that understanding to probe other domains of the law. ${ }^{57}$ Friedman's discussion of slave law not only lacks a full context; it is segregated in too many ways from the rest of the book. His insight that racism overcame the rational calculation of individual interest and instrumental use of law that so dominates the rest of the volume is left unexamined. As a result, instead of enhancing his analysis by adding other causal forces to his roster of agents at work in the law slavery persists as a peculiar institution in law as in society.

Slavery and republicanism suggest some of the limits of Friedman's analytical approach in recapturing the legal past. At too many critical points the image of the law as a mirror distorts the history of such vital topics. Friedman's refusal to grant the legal order a degree of autonomy is at once one of the most characteristic features of the functionalist school and its most critical limitation. In his 1983 article, Friedman conceded that he and others treated the law as "a dependent variable: not a cause, not an independent variable, but an effect." The result, he admits, is to depict the law "just as a puppet, dancing on its master's string." 58 The metaphor is particularly apt because in Friedman's view the law is merely an instrument that reflects the external nonlegal convictions and commitments of its users; it exerts no reciprocal constraints.

Friedman's assumptions deny him the full benefit of his prodigious reading in recent work in intellectual and social history. Many historians today work to depict their subject as a semi-autonomous realm within American society. In terms of law, that means trying to locate the range and temporal place of its characteristic language system, institutional assumptions, structural matrix, professional ideology, and ceremonies and rituals. Such a search must begin with the assumption that these traits set the law apart from other elements in society, as a quasi-independent source of authority, not a mere reflection of the balance of power among dominant social and economic forces. As a result, the relationship between the law and other realms of past experience such as religion or fami-

56. History, 1973, at 229.

57. In contrast, Finkelman offers this view of the relationship between law and society: "The conflict was undoubtedly social and economic at its roots, but the arguments were often legal. And as law is both a molder of society and a product of it, these legal arguments were as important and real as the economic and social issues." Finkelman, Imperfect Union 310 (cited in note 50 ).

58. Friedman, 17 Hist. Teacher, at 110. For a similar questioning of the notion of law as a reflection of society in terms of English legal history, see Robert C. Palmer, The Origins of Property in England, 3 Law \& Hist. Rev. 1-50 (1985). 
lies must be examined through an interactive and comparative model that recognizes that the legal order was more than an instrument for resource allocation and that, therefore, more than functional analysis is needed to understand its history. Only in this manner can we begin to understand the historical development of a distinctive American legal culture. ${ }^{59}$

Discrete visions of legal culture continually emerge in A History of American Law only to be covered over by Friedman's relentless functionalism. His constant evocation of the law as an instrument suppresses a full consideration of the legal order on its own terms. Instead, we hear muffled roars from the real world surges outside law's walls.

\section{CONCLUSION}

By retaining an approach that marginalizes the law, Friedman has undermined the value of his synthesis. The second edition of A History of American Law will remain the primary reference book in the field, but it is not likely to stimulate the kind of scholarship that Friedman desires. In the final analysis the book suffers from a passionlessness of substance and method. Everything is so clear, such a proper marriage of function and form, that controversy and excitement seem out of place. We just cannot understand why anyone in the past might have gotten exercised about legal issues. Similarly, the tone is so clear and authoritative, the presentation so lacking in contingency, that we are given no sense of the intense, often acrimonious debates among legal historians today.

"Our task," Bender tells us in one of many recent calls for synthesis in American history, "is not to decide whether to narrate but, rather, to conceive of a plot that is adequate to our proliferating knowledge about society."60 Lawrence Friedman has made an immense contribution to legal history in an effort to do that. But ultimately the second edition of $A$ History of American Law is just not adequate to our proliferating knowledge about the legal past. Nevertheless, in the attempt he offers a compendium of the valuable insights we can gain from the functionalist school of legal history. And in doing so he prods us to devise new tools of analysis. In legal history, as in so many branches of scholarship, it is the breadth of that search that is worth noting in conclusion. Disenchantment with so-

59. We need to approach the issues in terms like those political historians are using to understand American political culture. Particularly helpful are definitions such as that of political culture as "the system of empirical beliefs, expressive symbols, and values which define the situation in which political actions takes place." Lucien Pye \& Sidney Verba, Political Culture and Political Development 513 (Princeton, N.J., 1965); for an application of this definition see Jean Baker, Affairs of Party: The Political Culture of Northern Democrats in the Mid-Nineteenth Century (Ithaca, N.Y., 1983); id. Republicanism in the Antebellum North, 37 Am. Q. 538-39 (1987).

60. Bender, $73 \mathrm{~J}$. Am. Hist., at 122 (cited in note 7). 
cial science orthodoxies comes from all quarters, not just Critical Legal Studies. The recent, quintessentially liberal, bestseller Habits of the Heart expressed a kindred disillusionment. Robert Bellah and his co-authors added a call to recreate social science as a public philosophy to their critique of American individualism. In it they assert that "each generation, no matter how much it learns from tradition or how much it is aware that, unlike natural science, it cannot forget its founders, must still create a new social science for new realities."61 In A History of American Law Lawrence Friedman has crafted a tradition for American legal history; now it is time for legal historians to accept his insights but create a new social science.

61. Bellah et al., Habits of the Heart: Individualism and Commitment in American Life 297 (Berkeley, Cal., 1985). 
